To be cited as:

Borsa P., Collet A., Durand J.-D. 2004. - Nuclear-DNA markers confirm the presence of two anchovy species in the Mediterranean. Comptes Rendus Biologies 327, 1113-1123.

\title{
Nuclear-DNA markers confirm the presence of two anchovy species in the Mediterranean
}

Philippe Borsa*, Adeline Collet, Jean-Dominique Durand

Institut de Recherche pour le Développement, Département des Ressources Vivantes, Paris, France, and Laboratoire Génome Populations Interactions (CNRS / IFREMER / UM2), Station Méditerranéenne de l’Environnement Littoral, Sète, France

*Author to whom correspondence should be sent at the following address:

Institut de Recherche pour le Développement, BP A5, 98848 Nouméa, NouvelleCalédonie; tel +687 2607 41; fax +687264326 ; e-mail philippeborsa@yahoo.fr 
Abstract - Morphometric, allozymic and mitochondrial DNA variability previously indicated that Mediterranean anchovy Engraulis encrasicolus include two distinct forms, one of the inshore habitat, the other one of the open-sea habitat. Here, we showed that the two forms significantly differ by several morphological characters. To test the hypothesis, proposed previously, that the two forms are distinct biological species, we used length-polymorphic, exon-primed intronic PCR markers from the creatine-kinase multigenic family and genetically characterized anchovy samples collected in the northwestern Mediterranean and in the eastern Atlantic.

Large genetic differences were found between the two forms (Weir and Cockerham's $\wedge \theta=0.397$ to 0.586 ). In contrast, geographic variation in the open-sea form at the scale of the eastern Atlantic / northwestern Mediterranean was weak $(\wedge \theta=-0.006$ to 0.042 ). This again demonstrated considerable restriction to nuclear gene flow between inshore and open-sea anchovy populations. In addition to previous results from allozymes, this confirmed their status as distinct biological species, namely Engraulis albidus sp. nov. and Engraulis encrasicolus L.

gene flow / reproductive isolation / Atlantic / Mediterranean / Engraulis spp. / morphometrics / systematics

Résumé - Confirmation par les marqueurs ADN-nucléaires de la présence de deux espèces d'anchois en Méditerranée. Des résultats antérieurs sur la variabilité morphométrique et les polymorphismes allozymique et de l'ADN mitochondrial ont montré que l'anchois Engraulis encrasicolus comprenait deux formes distinctes en Méditerranée, une de l'habitat côtier, l'autre du large. Ici, nous montrons que les deux formes diffèrent de façon significative par plusieurs morphologiques. Nous utilisons comme marqueurs génétiques des introns de la famille multigénique de la créatine-kinase amplifiés par PCR à partir d'amorces situées dans les exons, polymorphes en longueur, pour analyser des échantillons d'anchois de Méditerranée nord-occidentale et de l'Atlantique oriental, afin de tester l'hypothèse, proposée antérieurement, que les formes côtière et océanique consistent en deux espèces biologiques distinctes. Des différences génétiques importantes ont été à nouveau observées entre les deux formes à quelques dizaines de $\mathrm{km}$ de distance $(\wedge \theta$ de Weir et Cockerham compris entre 0.397 et 0.586) alors que les différences géographiques entre populations de la forme océanique étaient faibles à l'échelle de l'Atlantique oriental et de la Méditerranée $(\wedge \theta=-0.006$ à 0.042$)$. Ceci, joint aux résultats antérieurs sur les allozymes, démontre une restriction importante du flux génique nucléaire entre les populations côtières et océaniques de l'anchois européen et permet de confirmer la présence d'espèces biologiques distinctes, nommément Engraulis albidus sp. nov. et Engraulis encrasicolus L.

flux génique / isolement reproducteur / Atlantique / Méditerranée / Engraulis spp. / morphométrie / systématique 


\section{Version française abrégée}

Les mécanismes de l’isolement reproducteur et de la spéciation restent peu documentés chez les organismes marins. L'étude génétique d'espèces sympatriques morphologiquement et écologiquement très proches permet d'aborder cette question fondamentale. Un modèle intéressant est l'anchois européen (Engraulis encrasicolus), chez lequel deux formes distinctes ont été récemment reconnues en Méditerranée, ceci à partir de données morphologiques et génétiques. Une de ces formes occupe l'habitat côtier dans le Golfe du Lion et le nord de l'Adriatique, tandis que l'autre forme, océanique, est présente au large des côtes de l'Atlantique nord-est, de la Méditerranée occidentale, de la mer Adriatique centrale et méridionale, ainsi que de la mer Ionienne. Des différences significatives de fréquences des allozymes et des haplotypes mitochondriaux ont été observées entre les deux formes, suggérant un fort degré d'isolement reproducteur entre celles-ci. Ainsi, l'hypothèse de deux espèces biologiques distinctes chez l'anchois de Méditerranée a-t-elle été émise. Des données indépendantes à des locus nucléaires non codants permettent de tester cette hypothèse. Ici sont présentées les données de fréquences alléliques de deux tels marqueurs : deux introns présentant un polymorphisme de longueur. Nos résultats apportent une distinction génétique supplémentaire entre les deux formes d'anchois méditerranéen, confirmant ainsi que le flux génique entre ces dernières est restreint.

Des échantillons d'anchois côtiers ont été capturés dans la baie du Cul-deBeauduc en Camargue (janvier $2001 ; 43^{\circ} 24^{\prime} \mathrm{N}, 03^{\circ} 35^{\prime} \mathrm{E}$ ) et dans la lagune de Mauguio dans le Gard (mai $2001 ; 43^{\circ} 36^{\prime} \mathrm{N}, 04^{\circ} 04^{\prime} \mathrm{E}$ ). Des anchois océaniques ont été capturés sur l'upwelling de Benguela au large de l'Afrique du Sud (septembre 2000 ; $32^{\circ} 10^{\prime} \mathrm{S}, \sim 17^{\circ} 30^{\prime} \mathrm{E}$ ) et dans le Golfe du Lion au large de Sète (décembre $\left.2000 ; 43^{\circ} 20^{\prime} \mathrm{N}, 04^{\circ} 00^{\prime} \mathrm{E}\right)$. Un échantillon supplémentaire provenait du marché aux poissons de Rabat au Maroc (février 2001). Pour l'analyse génétique des individus de chaque échantillon, des paires d'amorces oligonucléotidiques ont été choisies dans les exons de gènes après alignements de séquences homologues de poissons de familles différentes, de façon à amplifier, par la réaction de polymérisation cyclique (PCR) des introns en position homologue chez l'anchois. Nous avons ainsi dessiné les amorces de trois introns du gène de l'hormone de croissance (locus GH1, GH2, GH3 ci-après), un intron du gène de la somatolactine (SomLac2) et a priori le $6^{\mathrm{e}}$ intron du gène de la créatine-kinase (CK6). Après amplification par PCR, les allèles de longueur ont été séparés par électrophorèse sur gel de polyacrylamide vertical. Lors de tests préliminaires portant sur 5 à 10 individus de chacun des échantillons de Sète et du Cul-de-Beauduc, un polymorphisme de longueur a été observé à deux locus CK6 (CK6-1, CK6-2). Les autres locus testés étaient soit monomorphes (l'un de deux locus GH1, GH2, SomLac2), soit insuffisamment polymorphes (l'un de deux locus GH3) soit de lecture difficile sur les gels (second locus GH3). Afin de caractériser morphologiquement les deux formes, côtière et océanique, de l'anchois de Méditerranée occidentale, nous avons mesuré les six caractères suivants : rapport de la longueur de la tête sur la hauteur de la tête, nombre d'épines et de rayons branchus sur les nageoires dorsale et anale, et nombre de branchiospines. Ces caractères sont utilisés pour distinguer entre elles différentes espèces du au sein de la famille des Engraulididae. Les mesures ont été faites sur un échantillon de référence du Golfe du Lion comprenant 42 individus de l'anchois «blanc » ou côtier et 44 individus de l'anchois «bleu » ou océanique.

Des différences très significatives dans les fréquences alléliques aux locus CK6-1 et CK6-2 ont été observées entre échantillons d'anchois côtiers et océaniques ( $\wedge \theta$ de Weir et Cockerham compris entre 0.397 et 0.586 ) alors que les différences géographiques entre populations de la forme océanique étaient faibles à l'échelle de 
l'Atlantique oriental et de la Méditerranée $(\wedge \theta=-0.006$ à 0.042$)$. L'absence de différences génétiques significatives entre populations d'anchois océaniques éloignées de plusieurs milliers de $\mathrm{km}$ l'une de l'autre implique des flux géniques très élevés. A l’inverse, une restriction importante du flux génique est déduite des différences de fréquences alléliques entre échantillons d’anchois côtiers et océaniques prélevés à seulement quelques dizaines de km les uns des autres. Ceci confirme l'hypothèse, émise antérieurement à partir des données allozymiques, de l'isolement reproducteur entre les anchois océaniques et côtiers. Si les différences de fréquences alléliques au locus CK6-1 sont du même ordre que celles aux locus enzymatiques (c'est-à-dire faibles, mais significatives), celles au locus CK6-2 sont quant à elles très nettes, ce qui était déjà le cas des ADN mitochondriaux en Adriatique. Aucun des locus analysés pour l'instant chez l'anchois européen, qu'il s'agisse des locus enzymatiques, des locus introniques, ou de l'ADN mitochondrial, n'est diagnostique entre E. albidus et E. encrasicolus. Ceci laisse ouverte la possibilité que l'isolement reproducteur entre les deux espèces ne soit que partiel, ce qui ne met nullement en cause l'hypothèse de deux espèces biologiques. Une analyse en composantes principales réalisée sur six caractères morphométriques sépare sans ambiguïté les deux espèces. Les échantillons de spécimens des deux espèces diffèrent de façon significative par la morphologie de la tête, le nombre d'épines des nageoires dorsale et anale, ainsi que le nombre de branchiospines.

Que deux espèces puissent ainsi être distinguées chez l'anchois européen, poisson dont la biologie et l'écologie avaient pourtant fait l'objet de nombreux travaux du fait de son intérêt halieutique, appelle à un approfondissement de nos connaissances sur la systématique, l'écologie et l'évolution des Engraulididae en général. La mise en évidence d'espèces cryptiques a aussi des implications sur la gestion future des pêcheries, non seulement en Méditerranée, mais aussi partout dans le monde où l'on a détecté la présence sympatrique de deux formes, côtière et océanique, de l'anchois. Nous proposons le maintien du nom scientifique Engraulis encrasicolus Linné, 1758 pour la forme océanique de l'anchois européen et proposons le nom Engraulis albidus sp. nov. ("anchois blanc ») pour l'anchois côtier de Méditerranée (Golfe du Lion, Adriatique nord).

\section{Introduction}

Animals inhabiting the marine pelagic environment generally have broad distribution ranges, very large population sizes, and high potential for dispersal, which provide little opportunity for allopatric speciation. The mechanisms of their genetic differentiation, reproductive isolation, and speciation are poorly documented [1]. A way of approaching the fundamental question of speciation in marine organisms is to investigate the population genetics of morphologically and ecologically similar species that share a part of their range $[1,2]$. There are few known examples of cryptic diversity among species in the pelagic environment [2] but molecular studies have provided one such possible example in an oceanic mesopelagic fish [3] and hinted at some form of reproductive segregation between populations of European eel [4]. The hypothesis of cryptic species has also been recently proposed for European anchovy Engraulis encrasicolus [5].

Anchovies certainly are among the most common coastal pelagic fishes. They support the largest fisheries in the world with millions of tons harvested annually [6]. The geographic range of European anchovy, once thought to be confined to the coastal northeastern Atlantic Ocean and Mediterranean - Black Sea, is now believed to probably extend all along the coast of Western Africa to Southern Africa and a 
portion of the Indian Ocean [7,8]. Mitochondrial (mt)-DNA sequences effectively confirmed this by showing that Southern African anchovy (formerly E. capensis, which is also present in the western Indian Ocean) very recently derived from an $E$. encrasicolus population from the northeastern Atlantic or Mediterranean [8]. Two forms have actually been identified within E. encrasicolus in Europe, on the basis of morphology [9] and genetics (review in [5]). Anchovy of one form, coined Group I, occupy the inshore habitat of the Golfe-du-Lion (northwestern Mediterranean Sea) and the northern Adriatic Sea while Group II anchovy are found offshore in the oceanic waters of the Biscay Gulf in the northeastern Atlantic, the Western Mediterranean, and the central / southern Adriatic Sea and the Ionian Sea in the Eastern Mediterranean [5]. The distinction between the two Groups originally derived from the observation of small but consistent allozyme frequency differences between populations from different habitats, without relationship to geographic distance. Stronger mtDNA haplotype-frequency differences were observed when comparing the respective frequencies of mtDNA clades $A$ and $B$ [10] in the two Groups. However, mtDNA data for Group I are still scarce and neither $A$ or $B$ haplotypes were fixed in any of the Group I or Group II populations surveyed so far $[5,8,10]$. While the allozymic, morphometric and mitochondrial DNA data altogether strongly suggest that Group I and Group II anchovy are two biological species, independent non-coding nuclear-DNA data were needed to confirm this hypothesis. Here we report on two intronic nuclear-DNA loci that further distinguish from one the other the populations from inshore and oceanic habitats and provide compelling evidence of a barrier to neutral nuclear gene flow between them, thus confirming their status as distinct, biological species. In addition, morphometric data that discriminate between reference samples of the two species are provided.

\section{Materials and Methods}

Inshore anchovy were sampled by pelagic trawling on 03 January 2001 in Cul-de-Beauduc, a shallow cove located in Camargue, southern France $\left(43^{\circ} 24^{\prime} \mathrm{N}\right.$, $\left.04^{\circ} 35^{\prime} \mathrm{E}\right)$. Other inshore anchovy were captured using networks of nets and traps set on the bottom of the Mauguio lagoon, southern France $\left(43^{\circ} 36^{\prime} \mathrm{N}, 04^{\circ} 04^{\prime} \mathrm{E}\right)$ in May 2001. Anchovy from oceanic ('offshore') habitats included samples caught by pelagic trawling 18 nautical miles off Sète, in the Golfe-du-Lion, northwestern Mediterranean Sea $\left(43^{\circ} 10^{\prime} \mathrm{N}, 04^{\circ} 00^{\prime} \mathrm{E}\right)$ in December 2000 ; and from experimental fishing operations by South African government's agency for marine and coastal management (M\&CM) on the Benguela upwelling off South Africa ( 32 ${ }^{\circ} 10^{\prime} \mathrm{S}$, $\sim 17^{\circ} 30^{\prime} \mathrm{E}$ ) in September 2000. An additional sample, of unknown precise origin, consisted of 15 anchovy purchased from the fish market in Rabat, Atlantic coast of Morocco, in February 2001. The inshore and offshore sampling localities in the northwestern Mediterranean were distant from one the other by ca. 30 to 40 nautical miles (= ca. $50-70 \mathrm{~km})$.

To characterize the two forms (that is, coastal and oceanic, respectively) of anchovy in the northwestern Mediterranean, two morphometric and five meristic characters were measured and counted on reference samples of individuals: head depth, head length, apparent number of dorsal-fin spines, number of dorsal-fin rays, apparent number of anal-fin spines, number of anal-fin rays, and number of gillrakers on first lower-gill arch. The foregoing morphometric characters and meristic counts have been used for the distinction of species within the family Engraulididae [6]. Counts of fin spines and rays and of gillrakers were done under a stereo zoom microscope. We are aware that the first dorsal- and anal-fin spines may be difficult to detect from simple examination under a zoom microscope, because 
these may be hidden to the observer when they are too tiny and embedded in the flesh (R. Rodríguez-Sánchez, personal communication). Differences in counts of fin spines reported in the present study (see results) nevertheless reflect differences in their size and/or morphology. Measurements of head depth, head length, and standard length were made to the nearest $0.1 \mathrm{~mm}$ using a Vernier caliper. Head depth was measured perpendicular to the main axis of the body at the rear extremity of opercle; head length was measured from tip of snout to rear extremity of opercle. The ratio of head depth to head length was normalised using an arcsinetransformation. The reference samples included 42 randomly chosen individuals of coastal anchovy (including paratypes MNHN 2002-1718 to 1726), all from Cul-deBeauduc in the Golfe-du-Lion, and 44 randomly chosen individuals of oceanic anchovy (including voucher specimens MNHN 2002-1776 to 1805), all from Sète in the Golfe-du-Lion. Principal component analysis (PCA) was done on the matrix of individuals $\mathrm{x}$ characters using the ADE-4 software [11]. The statistical significance of the output of PCA was tested by permutations using Procedure DISCRIMINANT ANALYSIS/TEST implemented in ADE-4. Discriminant analysis [11] was also run on the same dataset.

Anchovy samples from five localities (details on sampling locations and sample sizes in Table 1) were genetically analysed at six intron loci. Exonic primer pairs were designed to specifically amplify introns 1, 2, and 3 of the growth hormone gene (hereafter designated as GH1, GH2 and GH3) and intron 2 of the somatolactin gene (SomLac2), using polymerase chain reaction (PCR), from the alignment of homologous nucleotide sequences in fishes (GENBANK: http://www.ncbi.nlm.nih.gov). The complete sequence of Lates calcarifer growth hormon gene (GENBANK U16816) was aligned with cDNA sequences of Lates calcarifer (GENBANK X59378), Thunnus sp. (GENBANK X06735), Sciaenops ocellatus (GENBANK AF065165) and Lateolabrax japonicus (GENBANK L43629) to locate introns and select conserved exon regions for PCR-priming. The three primer pairs we designed for loci $G H 1, G H 2$ and $G H 3$ respectively were: GH1-F (5'GAAYCCAGACCAGCCATGGAC-3') and GH1-R (5'GCGAGCAGGTGGAGGTGTTG-3'), GH2-F (5'-CAACACCTCCACCTGCTCGC-3') and GH2-R (5'-CCTGCAGGAAGATTTTGTTG-3'), and GH3-F (5'CCCSATYGACAAGCAYGAGAC-3') and GH3-R (5'GAYTCKACCAATCGATASGAG-3'). For the somatolactin gene, primers SomLac2$F$ (5'-ARGARAAACTTCTRGACCGRG-3') and SomLac2-R (5'-

ACCCACTTGGTYTTGTTGAG-3') were designed from the alignment of partial genomic sequence of Oncorhynchus keta (GENBANK D10638) with cDNA sequences of Siganus guttatus (GENBANK AB026186), Dicentrarchus labrax (GENBANK AJ277390), Paralichthys olivaceus (GENBANK M33695, M33696), Sparus aurata (GENBANK L 49205), Hippoglossus hippoglossus (GENBANK L02117), Cyclopterus lumpus (GENBANK L02118), Tetraodon miurus (GENBANK AF253066) and Gadus morhua (GENBANK D10639). Primers CK6F (5'-GACCACCTCCGAGTCATCTC-3') and $C K 7 R$ (5'-CAGGTGCTCGTTCCACATGA-3') [13], which are derived from, respectively, primers $C K 6-5^{\prime}$ and $C K 7-3^{\prime}$ [14], were used to specifically amplify Intron 6 of creatine kinase genes (CK6), actually a multigenic family.

For each individual, a piece of macerated muscle was DNA-extracted using a classical phenol-chloroform protocol, and the DNA used as template for PCR. Just before the PCR, the forward primer was radioactively labelled by incubating for 30 min at $37^{\circ} \mathrm{C}$ a mixture of $2 \mu M$ primer, $1 U$ T4 polynucleotide-kinase (Eurogentec, Liège, Belgium), and $1.7 \mu M(0.05 \mathrm{mCi})[\gamma$-33P]ATP (Isotopchim, Ganagobie, France). Ten microliters of reaction mixture comprising $4 \mu$ l DNA solution, $1.5 \mathrm{mM}$ MgCl2, $74 \mu M$ each dNTP, $0.4 \mu M$ reverse primer, $0.1 \mu M$ radioactively labelled forward primer, and $0.4 U$ Taq polymerase (Promega, Madison WI, USA) in its 
buffer, was subjected to 35 cycles of DNA denaturing $\left(12 \mathrm{~s}\right.$ at $\left.94^{\circ} \mathrm{C}\right)$, annealing $(12$ $\mathrm{s}$ at $52^{\circ} \mathrm{C}$ ) and elongating $\left(30 \mathrm{~s}\right.$ at $\left.72^{\circ} \mathrm{C}\right)$ followed by a final elongation step of $5 \mathrm{~min}$ at $72^{\circ} \mathrm{C}$. The PCR product was mixed with an equal volume of $95 \%$ formamide, 20 $\mathrm{m} M$ EDTA, $10 \mathrm{mM} \mathrm{NaOH}, 0.05 \%$ xylene cyanol and $0.05 \%$ bromophenol blue, and heat $\left(95^{\circ} \mathrm{C}\right)$-denatured. Size-polymorphism was assessed by subjecting the denatured PCR product to electrophoresis in $0.4-\mathrm{mm}$ thick polyacrylamide gel with $5 \%$ acrylamide and $42 \%$ urea. After migration, at $50 \mathrm{~W}$ for 5 hours, the gel was dried at $80^{\circ} \mathrm{C}$ for 1 hour in a vacuum drier and exposed against X-Omat autoradiographic film (Eastman-Kodak, Rochester NY, USA) for 12 hours or more depending on the level of radiation. Preliminary tests of polymorphism were conducted on 5-10 randomly chosen individuals from both Cul-de-Beauduc and Sète samples. PCR products from heterozygous individuals at both CK6 loci were excised from polyacrylamide gel. The excised piece of gel was put in $10 \mu l$ water in a microtube and subjected to two cycles of freezing / melting / vortex and centrifugation. The supernatant was used as template for non-radioactive PCR. The reamplified products were then purified using the PCR Product Pre-Sequencing kit of USB Corporation, (Cleveland $\mathrm{OH}, \mathrm{USA}$ ) and sequenced.

Correlations of alleles within individuals relative to the population, and those within populations relative to the total population, were estimated using estimators $\wedge f$ and $\wedge \theta$ [12], respectively. To give the expected distributions of $\wedge f$ and $\wedge \theta$ under the null hypotheses $f=0$ and $\theta=0$, respectively, 1000 pseudo-matrices of individuals $\mathrm{x}$ genotypes were generated from the original matrix by random permutations of alleles at a locus (for testing $\wedge f$-values) and of individuals (for testing $\wedge \theta$-values). The probability of occurrence of a parameter value larger or equal to the estimate was estimated as $P=(n+1) /(N+1)$ where $n$ is the number of pseudo-values larger than or equal to the estimate and $N$ is the number of random permutations [15]. The null hypothesis $f=0$ was rejected when $P<0.025$ (using a two-tailed test). The null hypothesis $\theta=0$ was rejected when $P<0.05$ (using a one-tailed test). The estimations of $f$ and $\theta$ and permutation tests were made using Procedure FSTATs in the computer package GENETIX [16].

\section{Results}

Two loci herafter designated CK6-1 and -2 were scored using the CK6F / $C K 7 R$ primer pair supposed to amplify Intron 6 of creatine-kinase genes. These exhibited size polymorphism on 5\% polyacrylamide gels (Fig. 1). The other loci tested exhibited either sample monomorphism (one of two GH1 loci, GH2, SomLac2), insufficient polymorphism (one of two GH3 loci), or were difficult to score (the other $G H 3$ locus). Five anchovy samples ( $N=82$ individuals in total) were then screened at loci $C K 6-1$ and -2 . Because of insufficient resolution, shorter alleles at locus $C K 6-2$ were pooled into compound allele $F$. Inferred genotype frequencies were compatible with Mendelian genetic determination [test of HardyWeinberg genotypic proportions: average fixation index over loci and samples, $\wedge f=$ -0.045 , not significant (see also Table 1)]. Two size-alleles at locus CK6-1 (102, $113)$ and three size-alleles at locus CK6-2 (098 twice, 100, F) were sequenced in both forward and reverse directions. All 6 sequences (GENBANK accession nos. AY486342 to AY486347) were aligned using BIOEDIT [17]. The difference in size between size-alleles 102 and 113 at locus CK6-1 was mainly due to a short transposon-like insertion/deletion (indel). The indel was 116 bp long and possessed at its 3' end a 8-bp short sequence (5'-TACAATGA-3') that flanks its 5 ' end in allele 102. Differences in size between alleles at locus CK6-2 were caused by shorter (1- 
$21 \mathrm{bp)}$ indels. Two locus-specific primer pairs were designed from the sequences. Specific to locus CK6-1 are forward CK6-1F (5'-

CGACATTGTAATGATGTTACAATGA-3') and reverse CK6-1R (5'-

ATTTCCTTTGGGTTGGCTCTTCTCT-3') primers (annealing temperature $=54^{\circ} \mathrm{C}$ ); specific to locus CK6-2 are forward CK6-2F (5' -

CTCAGAACTACATACCAAACCAATG-3') and reverse CK6-2R (5'-

ACTCACTGTAATTCTGAATAGAGCT-3') primers (annealing temperature $=52^{\circ} \mathrm{C}$ ). In PCR amplifications of a subsample of individuals, using these novel primer pairs, allele-size polymorphism at each locus was consistent with a Mendelian model of inheritance (data not shown). This confirmed the interpretations of gels loaded with the multiplex products from $C K 6-F / C K 7-R$-primed PCRs. Significant $\wedge \theta$-values were observed in all comparisons between oceanic anchovies and inshore anchovies; no significant $\wedge \theta$-value was found for the other pairwise comparisons (Table 2 ).

No significant effect of body size (standard length) on the ratio of head depth to head length was noted in sample Cul-de-Beauduc $\left(R^{2}=0.040 ; 40\right.$ d.f. $)$, but such a trend was apparent in the Sète sample $\left(R^{2}=0.222 ; 42\right.$ d.f.; $\left.P<0.01\right)$. The samples of specimens of the two species significantly differed by head morphology, numbers of anal- and dorsal-fin spines, and number of gillrakers on first lower-gill arch (Table 3). Principal component analysis, performed on the matrix of individuals defined by two morphometric measurements and five meristic counts, unambiguously separated the two samples as defined by their origin, i.e. coastal anchovy from Cul-deBeauduc vs. oceanic anchovy from off Sète (Fig. 2). Permutation tests confirmed the statistical significance of this grouping (Procedure DISCRIMINANT ANALYSIS/TEST of ADE-4 [11]: 10,000 permutations of individuals in the original data matrix; $P<<0.001)$. Discriminant analysis [11] also produced the linear function of morphometric and meristic variables that most differentiates the two groups shown by PCA (Legend to Fig. 2).

\section{Discussion}

Highly significant $\wedge \theta$-values were observed in all comparisons between oceanic anchovies and inshore anchovies while no significant differences were detected among samples within either oceanic or inshore anchovies. The lack of detectable genetic differences across vast distances (several thousand $\mathrm{km}$ ) within a Group implies high levels of intragroup gene flow. By contrast, considerable restriction in nuclear gene flow was demonstrated between Group I and Group II anchovies at very short distance (a few tens of $\mathrm{km}$ ). This is a confirmation of the hypothesis, raised previously from allozymes [5], that Group I (coastal) and Group II (oceanic) anchovies are reproductively isolated. In short, these should be considered as distinct, biological species. Allele-frequency differences between the two species at locus CK6-1 were of the same order as those at allozyme loci [5]. Those at locus CK6-2 were much stronger, of the same order as haplotype-frequency differences between the two species in the Adriatic Sea [5]. Persistent genetic differences, at neutral genetic markers, between coastal and oceanic forms of European anchovy imply that hybrids, if any, likely are at disadvantage, effectively demonstrating the ecological specialisation of each form. . However, the fact that no diagnostic locus so far has been found between the two species leaves open the possibility that reproductive isolation may only be partial. This does not mean the hypothesis of two biological species in European anchovy should be questioned: in the case of partial reproductive isolation such as that observed in hybrid zones, introgression rates at neutral 
markers are expected to vary according to their physical linkage with speciation genes [18, 19].

That cryptic species were found in European anchovy, a fish whose biology and ecology have received much attention because of its interest to fisheries [9, 10, 20, 21], hints that species richness in the family Engraulididae may be higher than currently thought [7]. This in turn calls to further studies on the systematics, ecology and evolution of anchovies. For instance, two distinct reproductive strategies have been recognized in Japanese anchovy (Engraulis japonicus) in relation with their habitat, distinguishing an inshore population from an offshore population [22]. Likewise, both coastal and oceanic spawning areas have been reported for Engraulis encrasicolus in the Gulf of Biscay [23]. If this is a stable feature of anchovy populations in this region, then distinct, perhaps reproductively isolated, spawning populations could have thus been detected. At the other extreme of the geographical range of European anchovy, the spawning grounds of Azov Sea anchovy are geographically separate and ecologically distinct from those of Black Sea anchovy (both currently E. encrasicolus) whereas both populations winter in the Black Sea [24]. Investigating population genetic structure in these model systems may further reveal some degree of reproductive isolation between oceanic and coastal populations. The present results for Atlantic / Mediterranean E. encrasicolus warrant further genetic studies of Japanese, Gulf of Biscay, and Black Sea anchovy populations and of other similar systems in the marine pelagic environment.

\section{Systematics and Distribution}

\subsection{Engraulis encrasicolus Linnaeus, 1758.}

No type is known for this species [25] and Linnaeus' original description [26] is too vague to allow the distinction between the two species referred to here (which are also Group I and Group II of [5]). For the sake of stability, we propose to arbitrarily maintain the specific name encrasicolus to the apparently most common and widespread anchovy species in the seas of Europe, that is Group II anchovy [5], also referred to as "oceanic" or "open-sea" anchovy [5, present work], and "blue anchovy" by fishermen in the Golfe-du-Lion and in the Adriatic Sea [9]. In the following, the term E. encrasicolus sensu lato (s.l.) will be used to designate all European anchovies without distinction, while the binomen E. encrasicolus will be kept exclusively in accordance with the present revision.

Type and voucher specimens. - Neotype, collected on 14 Dec. 2000, deposited by P. Borsa at Muséum National d'Histoire Naturelle, Paris, on 06 August 2002 (registered as MNHN 2002-1775). Voucher specimens (registered as MNHN 2002-1776 to MNHN 2002-1844) include specimens SET 26-30 of Fig. 1.

Neotype locality. - Eighteen nautical miles $(33 \mathrm{~km})$ off Sète in the Golfe-duLion, northern part of the Western Mediterranean.

Diagnostic features. - Flanks silvery, belly white, and back blue to dark blue with tones of brown depending on light conditions (Fig. 3). In the Golfe-du-Lion, mean ratio \pm standard deviation of head depth (measured perpendicular to the main axis of the body at the extremity of opercle, using a vernier caliper) to head length (measured from tip of snout to rear extremity of opercle) was $0.53 \pm 0.03$ (measures from 44 individuals ranging in size from $88.5 \mathrm{~mm}$ to $133.9 \mathrm{~mm}$ standard length). The average values for five other characters are given in Table 3 . In the northwestern Mediterranean, individuals smaller than $120 \mathrm{~mm}$ standard length are 
sexually immature (Y. Guennegan, B. Liorzou, J.-P. Quignard, personal communication). So far, positively identified from allozyme-frequency data [5, 9, $20,27,28]$, mitochondrial-DNA haplogroup-frequency data [5, 10], and size-allele frequencies at two creatine-kinase gene intron loci (namely, CK6-1 and CK6-2; present work). In the Golfe-du-Lion, CK6-1 polymorphic; most common allele at CK6-2 (098) yields DNA fragment of larger size than most common allele in $E$. albidus sp. nov. (Fig. 1; Table 1). The frequency of mitochondrial DNA type $A$ is comprised between 0.40 and 0.50 in the Gulf of Biscay, the northern Western Mediterranean, the Tyrrhenian Sea, and the Ionian Sea, all other haplotypes being of type $B[5,10,29]$. Frequency of most common electromorph at enzyme locus IDHP$2<0.65[5,9]$.

Habitat. - Pelagic, oceanic. At salinity $>38$ psu and depth $>75 \mathrm{~m}$ in the Adriatic Sea [5, 9].

Distribution. -Northern part of the Western Mediterranean, central and southern Adriatic Sea, Gulf of Biscay, Benguela upwelling. Further genetic studies are necessary to ascertain its presence in other regions in the eastern Atlantic and the Mediterranean.

\subsection{Engraulis albidus $s p$. nov.}

This name applies to Group I anchovy of [5], also referred to as "inshore" anchovy [5, present work] and "white anchovy" by fishermen in the Golfe-du-Lion, northern Western Mediterranean (hence the specific name albidus) and "silver anchovy" in the northern Adriatic Sea [9].

Type specimens. - Holotype, collected on 03 January 2001, deposited by P. Borsa at Muséum National d'Histoire Naturelle, Paris, on 06 August 2002 (registered as MNHN 2002-1716). Paratypes (registered as MNHN 2002-1717 to MNHN 20021774) include specimens CUL 41-45 of the present work and CUL 202 of Fig. 3.

Type locality. - Cul-de-Beauduc in Camargue, southern France, northwestern Mediterranean.

Diagnostic features. - Large silver stripe along flank, delineated on dorsal side by a thin longitudinal dark stripe. Back fleshy to light brown. General aspect paler than E. encrasicolus (Fig. 3). In the Golfe-du-Lion, mean ratio of head depth to head length was $0.56 \pm 0.03$ (measures from 42 individuals ranging in size from $61.6 \mathrm{~mm}$ to $98.8 \mathrm{~mm}$ standard length). The average values for five other characters are given in Table 3. Morphologically distinct from E. encrasicolus in the Adriatic but no simple diagnostic character proposed to date except raw multivariate scores from canonical analysis on morphomometric measurements collected using a 'truss network' $[5,9]$. Statistically significant morphological differences were found between northern/inshore Adriatic (E. albidus) and central/southern Adriatic ( $E$. encrasicolus) anchovy samples in more than half the univariate tests performed ([9]: parameters and data not explicited). Reaches 8 to $9 \mathrm{~cm}$ standard length at sexual maturity. Does not grow larger than $12 \mathrm{~cm}$ in the Golfe du Lion. Growth slower than E. encrasicolus in the Adriatic Sea [30]. In the northern Adriatic, frequency of mitochondrial DNA type $A$ comprised between 0.14 and 0.20 , all other haplotypes being of type $B[5,10]$. In the Golfe-du-Lion, allele 100 at locus $C K 6-1$ nearly fixed; most common allele at locus CK6-2 (100) yields DNA fragment of smaller size than most common allele in E. encrasicolus. In both Adriatic Sea and Golfe-duLion, frequency of most common electromorph at enzyme locus IDHP-2 >0.70 [5]. 
Habitat. - Pelagic from inshore waters, brackish lagoons, and estuaries in the northwestern Mediterranean. Observed in brackish lagoons from the beginning of spring to the end of summer. Leave the lagoons in autumn to the nearby coastal marine waters. Presumably spawn in lagoons in the summer (a presumption based on the observation of concentrations of small-sized anchovy together with large densities of eggs in the Thau lagoon, southern France, in July [31] and on the presence of sexually mature individuals of standard length comprised between $8 \mathrm{~cm}$ and $9 \mathrm{~cm}$ in the Mauguio and Prevost lagoons, southern France, as early as May (J.P. Quignard, personal communication)). At salinities $<38$ psu and depths $<50 \mathrm{~m}$ in the northern Adriatic Sea [5, 9].

Distribution. - So far, positively identified using allozyme frequency data [5, 9, 20, 27], or size-allele frequencies at two creatine-kinase gene intron loci (namely, locus CK6- 1 and locus CK6-2; present work). Shoreline of Camargue in the northwestern Mediterranean Sea; Mauguio, Prevost, and Thau lagoons in southern France; northern Adriatic Sea. These indications on distribution should be considered as preliminary. The use of genetic markers to search for the presence of E. albidus in other regions where E. encrasicolus s.l. or related species have been reported is warranted.

Acknowledgements. We thank Touryia Atarhouch, Pierre Fréon, Yvon Guennegan, Michel Houny, Jean-Pierre Quignard and Carl van der Lingen for kindly providing samples; Joseph Baly, Yanis Bouchenak, Isabel Calderón, Jacques Dietrich, and Marie Pascal for participating in the laboratory work; Patrice Pruvost for assistance at MNHN; Stewart Grant, Dominique Ponton and Rubén Rodríguez-Sánchez for insightful discussions and comments; and François Bonhomme for continued encouragement. This research was funded in part by the following institutions: French Government's CNRS (UMR 5000), IFREMER (URM16) and IRD (UR 081), for laboratory expenses; Republic of South Africa's M\&CM for sampling on the Benguela upwelling.

\section{References}

[1] S.R. Palumbi, Genetic divergence, reproductive isolation, and marine speciation. Annu. Rev. Ecol. Syst. 25 (1994) 547-572.

[2] N. Knowlton, Sibling species in the sea, Annu. Rev. Ecol. Syst. 24 (1993) 189-216.

[3] M. Miya, M. Nishida, Speciation in the open ocean, Nature 389 (1997) 803-804.

[4] T. Wirth, L. Bernatchez, Genetic evidence against panmixia in the European eel, Nature 409 (2001) 1037-1040.

[5] P. Borsa, Allozyme, mitochondrial-DNA, and morphometric variability indicate cryptic species of anchovy (Engraulis encrasicolus), Biol. J. Linn. Soc. 75 (2002) 261-269.

[6] P.J.P. Whitehead, G. Nelson, T. Wongratana, FAO species catalogue, vol. 7: Clupeoid fishes of the world (suborder Clupeoidae), an annotated and illustrated catalogue of the herrings, sardines, pilchards, sprats, shads, anchovies and wolf-herrings, part 2 - Engraulididae, FAO Fisheries Synop. 125 (1988) 305-579.

[7] P.J.P. Whitehead, Engraulididae, in: J.-C. Quero, C. Karrer, A. Post, L. Saldanha (Eds), Checklist of the fishes of the eastern tropical Atlantic (CLOFETA), vol. 1, UNESCO, Paris (1990) 228-229.

[8] W.S. Grant, B.W. Bowen, Shallow population histories in deep evolutionary lineages of marine fishes: insights from sardines and anchovies and lessons for conservation, J. Hered. 89 (1998) 415-426. 
[9] D.G. Bembo, G.R. Carvalho, N.Cingolani, E.Arneri, G.Giannetti, T.J. Pitcher, Allozymic and morphometric evidence for two stocks of the European anchovy Engraulis encrasicolus in Adriatic waters, Mar. Biol. 126 (1996) 529-538.

[10] A. Magoulas, N. Tsimenides, E. Zouros, Mitochondrial DNA phylogeny and the reconstruction of the population history of a species: the case of the European anchovy (Engraulis encrasicolus), Mol. Biol. Evol. 13 (1996) 178-190.

[11] J. Thioulouse, D. Chessel, S. Dolédec, J.-M. Olivier, AdE-4: a multivariate analysis and graphical display software. Stat. Comput. 7 (1997) 75-83.

[12] B.S. Weir, C.C. Cockerham, Estimating F-statistics for the analysis of population structure, Evolution, 38 (1984) 1358-1370.

[13] S. Chow, H. Takeyama, Intron length variation observed in the creatine kinase and ribosomal protein genes of the swordfish Xiphias gladius, Fisheries Sci. 64 (1998) 397-402.

[14] S. Palumbi, A. Martin, S. Romano, W.O. McMillan, L. Stice, G. Grabowski, The simple fool’s guide to PCR, version 2.0, Department of Zoology and Kewalo Marine Laboratory, University of Hawaii, Honolulu (1991).

[15] R.R. Sokal, F.J. Rohlf, Biometry, the principles and practice of statistics in biological research, 3rd edn, Freeman and Co, New York (1995).

[16] K. Belkhir, P.Borsa, N. Raufaste, L. Chikhi, F. Bonhomme, Genetix version 4.02, logiciel sous Windows ${ }^{\mathrm{TM}}$ pour la génétique des populations, Laboratoire Génome et Populations, Université Montpellier 2, Montpellier (2000).

[17] T.A. Hall, BioEdit: a user-friendly biological sequence alignment editor and analysis program for Windows 95/98/NT, Nucl. Acids Symp. Ser. 41 (1999) 95-98.

[18] N.H. Barton, Gene flow past a cline, Heredity 43 (1979) 333-339.

[19] N.H. Barton, The effects of linkage and density-dependant regulation on gene flow, Heredity 57 (1986) 415-426.

[20] D.G. Bembo, G.R. Carvalho, N. Cingolani, T.J. Pitcher, Electrophoretic analysis of stock structure in Northern Mediterranean anchovies, Engraulis encrasicolus, ICES J. Mar. Sci. 53 (1996) 115-128.

[21] I. Palomera, P. Rubiés (eds.), The European anchovy and its environment, Sci. Mar. 60 suppl. 2 (1996).

[22] T. Funamoto, I. Aoki, Reproductive ecology of Japanese anchovy off the Pacific coast of eastern Honshu, Japan, J. Fish Biol. 60 (2002) 154-169.

[23] L. Motos, A.Uriarte, V. Valencia, The spawning environment of the Bay of Biscay anchovy (Engraulis encrasicolus L.), Sci. Mar. 60 suppl. 2 (1996) 117-140.

[24] A.K. Chashchin, The Black Sea population of anchovy, Sci. Mar. 60 suppl. 2 (1996) 219-225.

[25] W.N. Eschmeyer, Catalog of fishes, California Academy of Sciences, San Francisco (1998).

[26] C. Linnaeus, Systema naturae, 10th edn., Laurentii Salvi, Stockholm (1758).

[27] N. Pasteur, P. Berrebi, Structure génétique des populations naturelles d'animaux laguno-marins sur des bases de génétique biochimique et d’écologie (Contrat ${ }^{\circ}$ 83.J.0024 du Ministère de la Recherche, Direction du Développement Scientifique et Technologique et de l’Innovation), Université des Sciences et Techniques du Languedoc, Montpellier (1985).

[28] S. Tudela, J.L. García-Marín, C. Pla, Genetic structure of the European anchovy, Engraulis encrasicolus, in the north-west Mediterranean, J. Exp. Mar. Biol. Ecol., 234 (1999) 95-109.

[29] D.G. Bembo, G.R. Carvalho, M. Snow, N. Cingolani, T.J. Pitcher, Stock discrimination among European anchovies, Engraulis encrasicolus, by means of PCR-amplified mitochondrial DNA analysis, Fishery Bull. U. S. 94 (1995) 31-40.

[30] D. Levi, M.G. Andreoli, E. Arneri, G. Gianetti, P. Rizzo, Otolith reading as a tool for stock identification, Fisheries Res. 20 (1994) 97-107.

[31] J.-Y. Lee, C. Juge, Observations morphologiques et biologiques sur les anchois (Engraulis encrassicholus) du golfe du Lion, Rapp. P.-V. Réun. Comm. Int. Explor Sci. Mer Méd. 18 (1965) 221-224. 
Table 1. Engraulis spp. Allele frequencies at two nuclear-DNA loci in 5 samples from the eastern Atlantic and the northern Western Mediterranean. Benguela, Benguela upwelling off Cape Peninsula, South Africa, September 2000; Rabat, Rabat fish market, Morocco, February 2001; Sète, 18 miles offshore, Golfe du Lion, northern Western Mediterranean, December 2000; Cul-de-Beauduc, inshore, shallow bay in the Camargue region, northern Western Mediterranean, January 2001; Mauguio, Mauguio lagoon, northern Western Mediterranean, May 2001. $N$, sample size; $\wedge f$, Weir and Cockerham's estimate of the correlation of alleles within individuals relative to the population [12]

\begin{tabular}{|c|c|c|c|c|c|}
\hline \multirow{2}{*}{$\begin{array}{l}\text { Locus, } \\
\text { Allèle }\end{array}$} & \multicolumn{5}{|l|}{ Sample } \\
\hline & Benguela & Rabat & Sète & $\begin{array}{l}\text { Cul-de- } \\
\text { Beauduc }\end{array}$ & Mauguio \\
\hline \multicolumn{6}{|l|}{ CK6-1 } \\
\hline 095 & - & 0.03 & 0.03 & - & - \\
\hline 098 & - & - & - & 0.02 & - \\
\hline 100 & 0.70 & 0.90 & 0.85 & 0.97 & 1.00 \\
\hline 102 & - & - & 0.03 & - & - \\
\hline 103 & - & - & 0.08 & - & - \\
\hline 113 & 0.25 & 0.07 & 0.03 & 0.02 & - \\
\hline 115 & 0.05 & - & - & - & - \\
\hline$(N)$ & (10) & (15) & $(20)$ & (32) & (9) \\
\hline$\wedge f$ & -0.301 & -0.050 & -0.086 & -0.008 & - \\
\hline \multicolumn{6}{|l|}{ CK6-2 } \\
\hline 096 & - & 0.03 & - & - & - \\
\hline 098 & 0.70 & 0.70 & 0.73 & 0.15 & 0.06 \\
\hline 099 & - & - & - & 0.03 & - \\
\hline 100 & 0.25 & 0.20 & 0.10 & 0.74 & 0.89 \\
\hline F & 0.05 & 0.07 & 0.18 & 0.08 & 0.06 \\
\hline$(N)$ & (10) & (15) & (20) & (31) & (9) \\
\hline$\wedge f$ & 0.265 & 0.314 & -0.128 & -0.211 & -0.032 \\
\hline
\end{tabular}


Table 2. Engraulis spp. Pairwise $\theta$-estimates between populations.

\begin{tabular}{|c|c|c|c|c|}
\hline \multirow[t]{2}{*}{ Sample } & \multicolumn{4}{|l|}{ Sample } \\
\hline & Rabat & Sète & $\begin{array}{l}\text { Cul-de- } \\
\text { Beauduc }\end{array}$ & Mauguio \\
\hline Benguela & $0.007^{\mathrm{NS}}$ & $0.042^{\mathrm{NS}}$ & $0.328 * * *$ & $0.403 * *$ \\
\hline Rabat & & $-0.006^{\mathrm{NS}}$ & $0.349 * * *$ & $0.457 * *$ \\
\hline Sète & & & $0.397 * * *$ & $0.586 * * *$ \\
\hline Cul-de-Beauduc & & & & $0.008^{\mathrm{NS}}$ \\
\hline
\end{tabular}

NS not significant; ** $p<0.01 ; * * * p<0.001$ (1000 permutations)

Table 3. Engraulis albidus sp. nov. and E. encrasicolus: mean \pm SD for six morphometric and meristic characters in two reference samples (Cul-de-Beauduc for E. albidus, Sète for E. encrasicolus). H/Lt, ratio of depth of head to length of head; $D n b$, number of dorsal-fin spines; $D b$, number of dorsal-fin rays; $A n b$, number of anal-fin spines; $A b$, number of anal-fin rays; $L w G$, number of gillrakers on first lower-gill arch. $P$, probability of value greater than or equal to the observed difference under the null hypothesis of equality of means (Student's $t$-test [15]).

$\begin{array}{lllll}\text { Character } & \text { E. albidus } & \text { E. encrasicolus } & \text { t-test } \\ & \text { mean } \pm \mathrm{SD} & (N) & \text { mean } \pm \mathrm{SD} & (N)\end{array}$

\begin{tabular}{lrrrrr}
\hline & & & & & \\
$\arcsin \sqrt{ } H / L t$ & $0.85 \pm 0.03$ & $(42)$ & $0.82 \pm 0.03$ & $(44)$ & $P<0.001$ \\
Dnb & $3.00 \pm 0.00$ & $(29)$ & $2.70 \pm 0.46$ & $(27)$ & $P=0.001$ \\
$D b$ & $12.28 \pm 0.83$ & $(29)$ & $12.19 \pm 0.82$ & $(27)$ & $P=0.687$ \\
$A n b$ & $2.90 \pm 0.30$ & $(29)$ & $2.57 \pm 0.50$ & $(30)$ & $P=0.004$ \\
$A b$ & $15.21 \pm 0.96$ & $(29)$ & $15.27 \pm 1.39$ & $(30)$ & $P=0.851$ \\
$L w G$ & $34.52 \pm 1.59$ & $(29)$ & $35.67 \pm 1.90$ & $(30)$ & $P=0.016$ \\
& & & & & \\
\hline
\end{tabular}


Fig. 1. Engraulis spp. PCR amplification using primers CK6F and CK7R [13]. Autoradiography of PCR products after electrophoretic migration in vertical denaturing polyacrylamide gel of reference individuals SET 26-30 from sample Sète and CUL 41-45 from sample Cul-de-Beauduc, and designation of alleles at loci CK6-1 (Locus 1) and CK6-2 (Locus 2).

Fig. 2. Engraulis albidus sp. nov. and E. encrasicolus. Principal component analysis (output from ADE-4 [11]): annotated scores for components 1 (horizontal; $36.0 \%$ of total inertia) and 2 (vertical; $19.0 \%$ of total inertia) of individuals of two reference samples (respectively, Cul-de-Beauduc and Sète), characterised by two morphometric measurements and five meristic counts. $A b$, number of anal-fin rays; Anb, number of analfin spines; $D b$, number of dorsal-fin rays; $D n b$, number of dorsal-fin spines; ' $H$ ', ratio of depth of head to standard length (arcsin $\sqrt{ }$-transformed); ' $L t$ ', ratio of length of head to standard length (arcsin $\sqrt{ }$-transformed); $L w G$, number of gillrakers on first lower-gill arch. The first discriminant equation [11] derived from the same dataset was $-0.130 \cdot A n b-0.006 \cdot A b+0.117 \cdot D n b-0.026 \cdot D b-0.135 \cdot L w G+0.454 \cdot \arcsin \sqrt{ } H / S L+$ $0.589 \cdot \arcsin \sqrt{ } L t / S L$, where $S L$ is standard length.

Fig. 3. Above: Engraulis albidus sp. nov. specimen no. CUL 202 (MNHN 2002-1774: paratype) from Cul-deBeauduc, January 2001, standard length (SL) 94.5 mm; below: E. encrasicolus specimen no. SET 102 from Sète, December 2000, SL 99.2 mm. 
$\begin{array}{llllllllll}\begin{array}{l}\text { SET } \\ 26\end{array} & 27 & 28 & 29 & 30 & 41 & 42 & 43 & 44 & 45\end{array}$

Locus 1

095

100

Locus 2

098

099

100

$\mathrm{F} / \mathrm{F}$

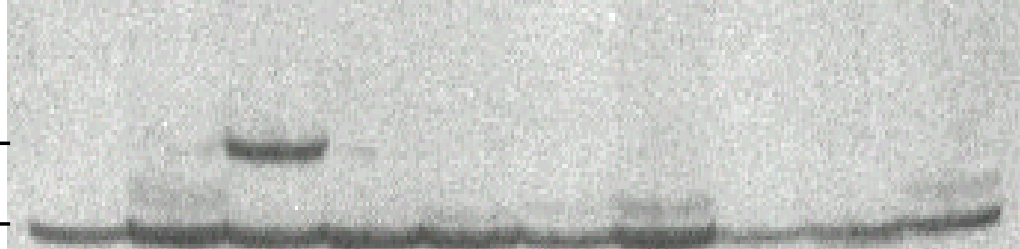

$\overline{\bar{F}}$ 


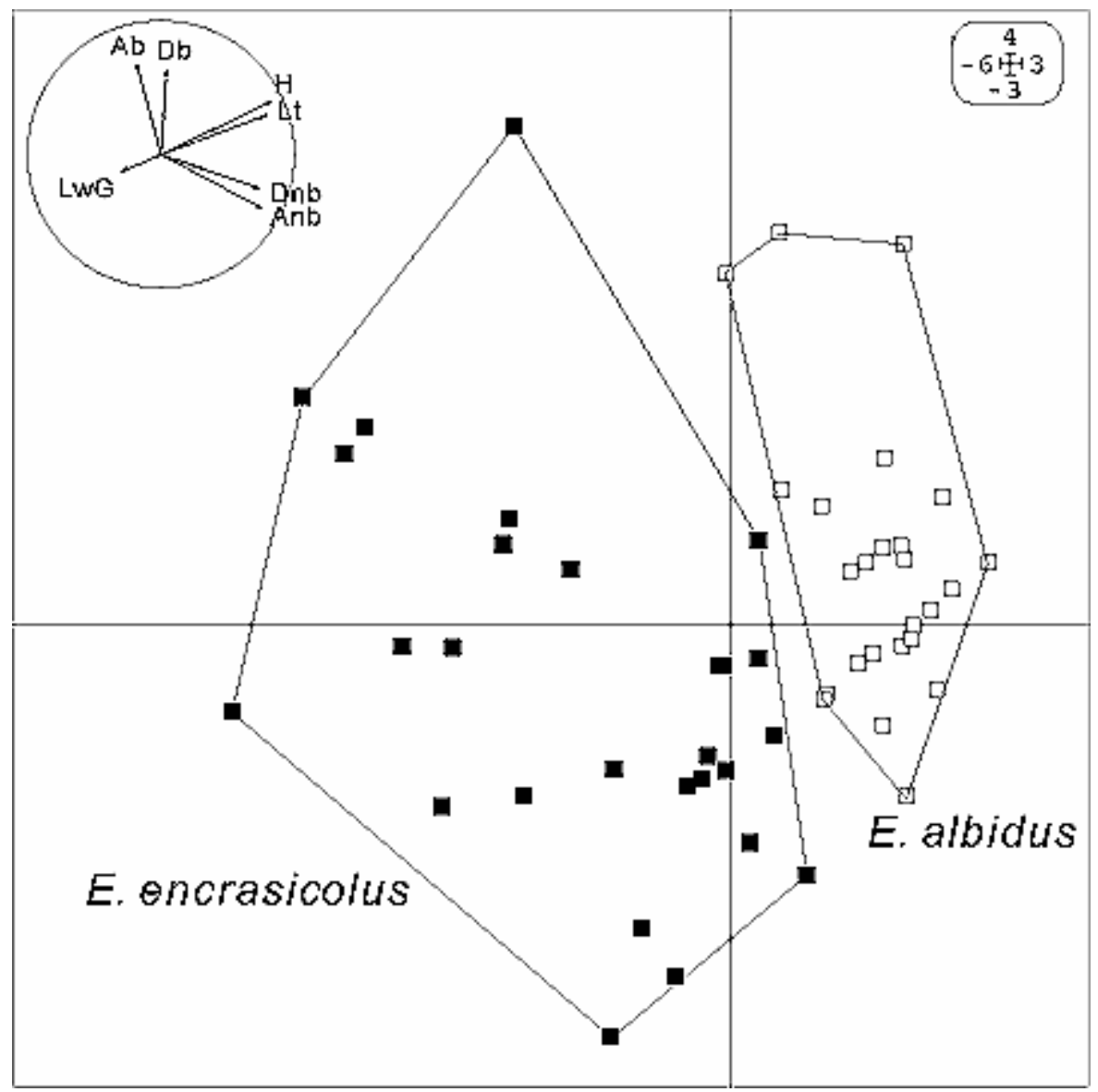




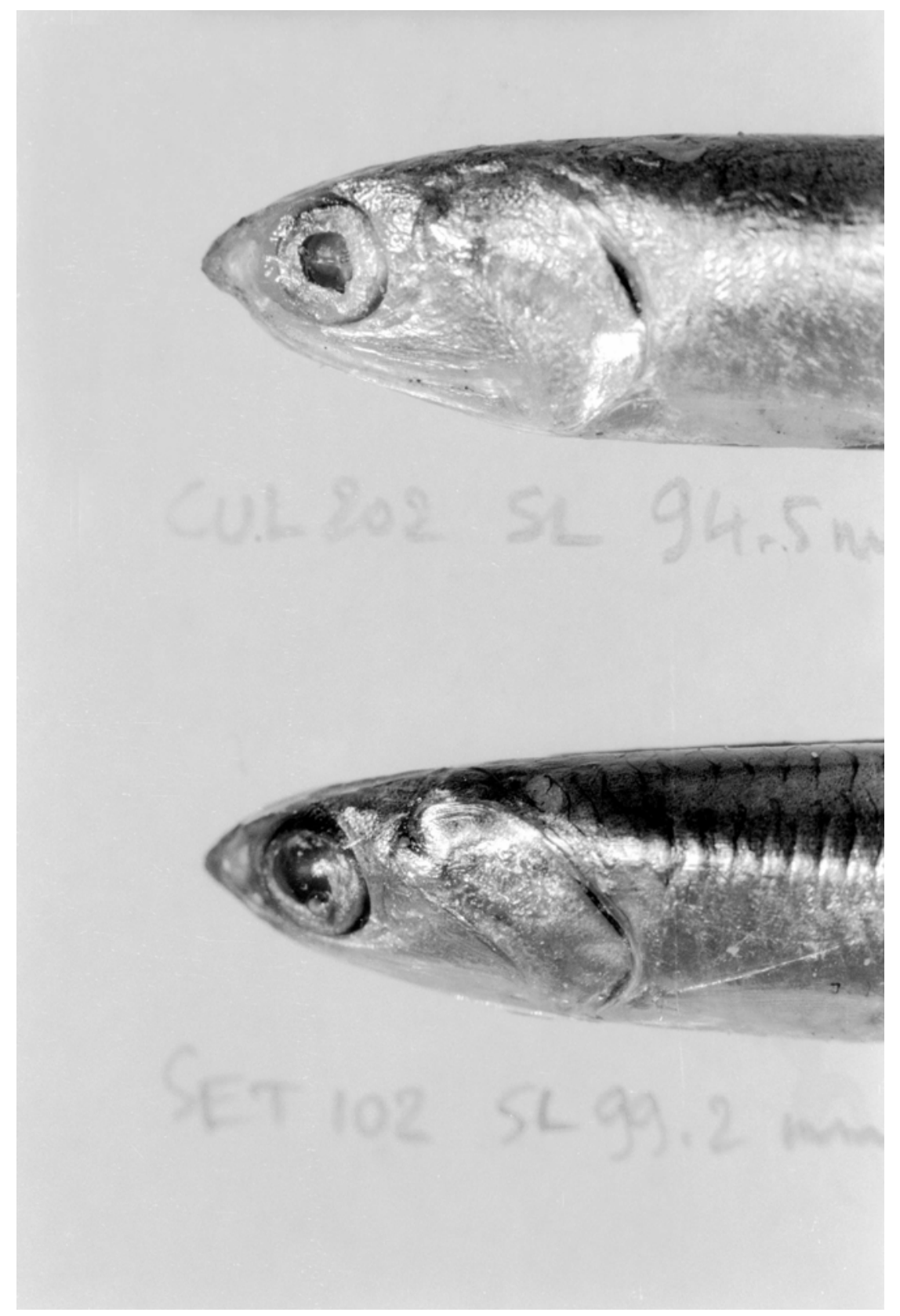

